\title{
Plant Naming Patterns as a Reflection of Language Image of the World
}

\author{
Khoshimkhujaeva Mokhiruh \\ Faculty of Foreign Philology, National University of Uzbekistan, Uzbekistan
}

Copyright $\bigcirc 2017$ by authors, all rights reserved. Authors agree that this article remains permanently open access under the terms of the Creative Commons Attribution License 4.0 International License

\begin{abstract}
The paper is devoted to analysis of English and Uzbek plant naming patters as a reflection of original language image of the world. Particularly, by answering the questions how and why some elements of national culture and mindset are used for naming plants, we explored the principles of perception and categorization of the world by English and Uzbek people. Based on the theory of "language image of the world" first suggested by Weisgerber and revised then by Whorf, we tried to understand what associations are put under the base of some popular patterns of naming the plants both in English and Uzbek, and how these association can explain general and specific features of the languages' image of the world. To achieve this goal we divided all the collected plant names into special association fields (Religion, animals and house belongings). Plant name analysis within these special fields expressing national specific worldview most vividly, showed us how notions related to religion, animals and house belongings (artifacts) can serve as a mean of fixing information about different properties of plants in the minds of the nations. As a result we discovered particular analogous and peculiar features of English and Uzbek worldviews.
\end{abstract}

Keywords Language Image of the World, Plant Names, English and Uzbek Languages

\section{Introduction}

It is generally known that people live in a close connection with world of Flora. Each plant has several features that are of a different value for people. Every nation usually indicates this value in the name of a plant by means of special naming pattern. Since each nation is unique, in terms of historical development, lifestyle, social life and culture, plant naming patterns also vary from language to language reflecting specific features of world perception of the nation. Therefore investigating the plant naming patterns in unrelated and different structured languages is very important for contrastive and cognitive linguistics as well. Our research deals with contrastive analysis of English and Uzbek plant naming patterns. Namely, by answering the question: why and how a plant is given a name in particular way, we tried to explain the peculiarities of English and Uzbek perception of the world and its reflection in the language.

\section{Research Background}

The research is based on the theory of "language image of the world" suggested by Leo Weisgerber [1]. According to this theory: 1. the linguistic image of the world - is the system of all possible contents: spiritual that define the uniqueness of the culture and mentality of particular language community; it is a result of the historical development of the ethnic group and language; it exists in one homogeneous self-consciousness of a particular language community and is transmitted to future generations through a special outlook, rules of behavior, lifestyle fixed by means of language. Further research of the theory is carried out by Sukalenko [2], who states that language is a fact of culture, an integral part of the culture, as language accumulates the key concepts of culture, translating them into symbolic incarnation - words. Language image of the world created by nations is a subjective image of the objective world, and it is highly anthropocentric as it bears the features of the human way of world discernment.

Following this conception gives us a deeper understanding of why some plant naming patterns are preferred in English or Uzbek; and what types of cognitive associations about the plants are common for these nations.

The paper takes the method of motivational analysis as a main device to analyze the factual material (plant names). In particular, by investigating the motive of plant nomination and respective cultural circumstances related to it we try to reveal unique plant naming patterns for English or Uzbek. In this research, motivational analysis of plant names is conducted in a cognitive approach. This approach helps us to reconstruct the principles of perception and categorization of the world by English or Uzbek people and gives a chance to describe the nations' language image of the world, which is 
present in the consciousness of the nations and organizes their mental lexicon.

\section{Data Collection}

For the analysis we considered only common plant names, regarding to the fact that they are more colorful and expressive than scientific ones, and can display differences between English and Uzbek language worldview more vividly. The factual material consists of 32 English and 15 Uzbek common plant names retrieved from etymological dictionaries and lexicographical materials. In particular, English plant names and their origin were picked out from following sources: Online Etymology Dictionary [3], On the popular names of British plants, being an explanation of the origin and meaning of the names of our indigenous and most commonly cultivated species [4]. Rustic Speech and Folk-Lore [5]. Historical Common Names of Great Plains Plants Volume I: Historical Names [6].

It should be noted that there is a serious lack of material in Uzbek as plant names have not been investigated in etymological or motivational aspect yet. We found neither etymological nor motivational entries referring to Uzbek plant names. Existing resources like O'zbek shevalari leksikasi [7], O'rta osiyodagi foydali va zararli o'simliklarning maxalliy nomlari lug ati [8] include only names of plants and no further information. Thus we had to analyze naming patterns only by studying physical characteristics (the way of growing, color, size, shape, practical usage, symbolism and etc.) of the plant itself, and compare them with names to find the motive of nomination. In the article each common plant name is given in italics with its scientific botanical name in round brackets. Uzbek plant names are accompanied with literal translation in English.

\section{Data Analysis}

According to Panasenko [9], the process of naming plants consists of two stages. As she states, in giving names to plants a man first of all sorts them out of the general class of plants, then identifies them with already known to him plants or objects, being guided thus by his personal experience that is his outlook, culture, religion, lifestyle, location and etc. In other words, when naming a plant, a man associates a plant or its features like form, size, color, substance, texture, and volume with other objects which often occur to be cultural elements. The research showed that both in English and Uzbek, plants are associated mostly with cultural elements of three specific association fields: Religion, Animals and Artifacts. In our opinion, the analysis of plant names within these three specific association fields expressing national specific worldview most vividly, showed us how notions related to religion, animals and house belongings (artifacts) can serve as a mean of fixing information about different properties of plants in the minds of the nations.

\subsection{Religion}

There is no doubt that religion is a source of enrichment and an important contributor to the sustainable development of different cultures. In Western culture, many plants were used allegorically, as Christian symbols. Although plant's religious significance is no longer at the fore, the religious references in their names persist. The following are some of the English plant names associated with Biblical subjects:

Virgin Mary, Virgin Mary's Honeysuckle, Virgin Mary's Milkdrops, Lady's Milk-sile, are names of the lungwort (Pulnumaria officinalis), referring to the legend that during the flight into Egypt some of the Blessed Virgin's milk fell on its leaves, as she nursed the infant Jesus. The same legend is also told to account for like spots on the leaves of Blessed Thistle, Our Lady's Thistle (Carduus marianus). Another legend says that the Virgin Mary, when thirsty, met with a cow and after using the broad leaf of the thistle as a drinking-cup, willed that the species should ever after be called by her name, and bear the stains of the milk on its leaves (Wright [5]: 333). We suppose that religious components in these plant names are alluded to their medical properties, they were used to cure many diseases in old times.

Other religious components include:

Archangel (Angelica archangelica), probably from its being in blossom on the Archangel St. Michael's day, the 8th of May, old style, and thence supposed to be a preservative against evil spirits and witchcraft, and particularly against the disease in cattle called elfshot [4]; Christmas Rose (Helleborus niger), from its open rose-like flower, and its blossoming during the winter months [4]; Holy Rope (Eupatorium cannabinum), a plant that from its hemp-like leaves was fixed upon as the one that yielded the rope with which Jesus was bound; just as there was a Christ's thorn, a Christ's gall, a reed-mace, a Christ's ladder, etc., found to represent the other incidents of the Crucifixion [4].

As we see, in English culture, there is a special tradition of associating the plants with religious legends. Mainly on the basis of the tradition stands an interpretation of plants` unusual features (negative or positive) from the point of religion.

It is widely known that religion is an inseparable element of oriental civilization. Uzbek culture and language as a part of this civilization was greatly affected by Islam. However when analyzing Uzbek plant names we discovered that there were very few plant names motivated by religion. We found only 3 names with religious elements. Probably, it is due to the fact that in religious traditions of Uzbeks all living thing, even inanimate objects created by God cannot be sanctified or connected to religious personages. From this point of view, we suppose that these names are uzbekized names borrowed from Arabian or Persian:

Maryam darahti (Vitex agnus-castus) [7] - Virgin Mary tree, Vitex for centuries has been traditionally used for the treatment of women ailments. Accordingly the component Maryam - Mary denotes the world of women and used here 
to show that this plant refers to women mostly; Khassa Muso (Abelia corymbosa) [8] - Staff of Moses, stem of a plant resembles the shape of a staff of Moses the prophet. The beauty of the flowers of the plant is associated to magical properties of the staff; Abu zhahl tarvuzi (Bryonia dioica) [8] - Abu Zhahil's watermelon, Abu Zhahil was initially bitter enemy of the Prophet Muhammad, later becoming his successor - the story associated with toxic and at the same time the healing properties of plants.

\subsection{Animals}

Animal world is of paramount importance, not only in our lives, but also in the language. On one hand animals are most similar to us, so we have a strong need to be clearly separated from them, but, on the other hand, they represent a huge inspiration for us, and we cannot do without them (Stepanova [10]).

Animals are used in plant names to include specific information about the plant, so that to show the most important feature of the plant for human being. Often animal components chosen for that purpose, are domestic animals that live in our hoses. For instant, in English, to indicate that a plant differs from other species within the same family by size a component - 'horse' is used:

Horse-radish (Cochlearia armoricia) the common name preserves the once-common figurative adjectival sense of horse as "strong, large, coarse," the same meaning we can find in the following plant names: Horse mushroom, Horse-balm, Horse parsley, Horse-mussel, Horse mint [3]. All of these plants somehow stand out among other species in the same family by size of the fruits, leaves or stem; Horse-chestnut (Aesculus hippocastanum) from horse + chestnut, the plant is said to have been so called because of its large fruits: the nut resembles that of the edible chestnut but is bitter to the taste [3].

In Uzbek language 'horse' is replaced by 'camel': Tuyayaproq (Rheum turkestanicum Janisch.)[8] camel+leaves, the plant is so called because of its huge leaves; Tuyapaypoq (Convolvulus fruticosus Pall.)[8] camel+socks, the plant has relatively big flowers which resemble socks.

Both in English and Uzbek, the word 'dog' has disparaging meanings (poisonous, smelly, worthless, wild, and thorny) and mainly used for indicating plants' negative features:

Dog rose (Rosa canina), a wild kind not valued for scent or beauty. The word 'dog' has a meaning of wild and scentless, on the account of the plant's relatively bad smell and appearance than a real rose [4] 68. Dog fennel (Anthemis cotula) is so called on the account of its bad smell, and fennel-like leaves [11]; Ituzum (Solanum nigrum L.) [7] dog+grape, the poisonous berries of the plant are interpreted by the words 'dog' (poisonous) and 'grape' (berry). Itkuchala [8] (Eminium Lehmanni O. Ktze) - dog+eminium, the word ' $d \mathrm{gg}^{\prime}$ is used here, to indicate that the plant is very poisonous.

Also, in Uzbek plant names, the animal component 'donkey' can expresses negative features:

Eshakmiya (Vexibia alopecuroides (L.) Yakovl) [8] donkey+brain, this highly toxic plant which can cause confusion in humans and animals. Eshakbodring (Ecballium elaterium (L.) A. Rich.) [8] - donkey+cucumber, this plant gets its unusual name from the fact that, cucumber like fruits are highly poisonous, and when ripe, they squirt a stream of mucilaginous liquid containing seeds of the plant.

\subsection{Artifacts}

The analysis of artifacts as a component of plant name in English and Uzbek made us to assume that appropriate artifacts are of a bigger importance in one culture than in another. For instance, some linguistic researches show that items of clothing - headgear were very popular with English people in all social layers. Biggam [12] who investigated English plant names formed from headgear, indicates that great variety of headgear were adopted by English speakers to name certain plants. He states that the motivation for the use of headgear-names is to aid plant-recognition by likening parts of them to widely familiar, everyday items. Headgear-names, in many cases, must have suggested themselves, since something worn on the top of a person often refers to a flower or other feature at the top of a plant stem (Biggam [12]: 65). Followings are some of such plant names:

Granny's Nightcap (Stellaria holostea) with partially opened white flowers resembling a simple cap with an out-turned, lobed edge. With the same name, and of a similar appearance to the flower, but with a less out-turned edge, is the Wood Anemone, also known as Lady's Nightcap[12]; Capdockin (Petasites vulgaris) is so called from the traditional use of its large leaves for wrapping [12]. Besides above mentioned names we found several plant names containing artifacts which can be classified into a subgroup called - Lady`s.

Other items of clothing and toilette are recorded by Nowick [6]:219. She presented more than 10 examples of names with the content Lady's + artifact. But Nowick did not provide origin of the names, so we had to find it from other sources. Some of them are listed below:

Lady's-glove (Digitalis purpurea) named so from the resemblance of its flower to the finger of a glove [4]; Ladies' laces (Phalaris arundmacea) dodder, the name derives from plant's string like stems [4]; Lady's-mantle (Alchemilla alpine) named so from the Vandyke shaped edge of the leaf [4]; Lady's-shoes-and-stockings (Lotus corniculatus) the name refers to the appearance of flowers resembling women shoes and the seed pods on their stalk resembling stockings; Lady's slipper (Cypripedium L.) the name comes from the shape of the labellum of its flower [4]; Lady's-purse is another name for Lady's slipper; Lady's-smock (Cardamine pratensis) the name derives from the resemblance of its white flowers to little smocks hung out to dry, as they used to be once a year at that season especially [4]; Lady's bedstraw 
(Galium aparine) In Europe, the dried, matted foliage of the plant was once used to stuff mattresses. Several of the bedstraws were used for this purpose because the clinging hairs cause the branches to stick together, which enables the mattress filling to maintain a uniform thickness (Tull [13]:145); Lady's-bower (Clematis virginiana) so named from its aptness in making of arbors, bowers, and shady covertures in gardens [4]; Lady's-comb (Scandix pecten-veneris) the name comes from the long slender parallel beaks of seed-vessels [4]; Lady's-cushion (Armeria vulgaris) so called from its close cushion-like growth. [4].

Large number of plant names with the content Lady`s + artifact demonstrates the special place of artifacts (toilette accessories) referring to World of Woman in English national mindset and culture.

In Uzbek plant lexicon we found several names with artifacts as well. In such plant names artifacts mainly refer to everyday life of middle class people. Often the names have the content of people + artifact or animal + artifact. Some examples presented below:

Burgansupurgi (Artemisia annua L.) [8] - flea + broom, this plant contains essential oils with a specific smell. It is used as an insecticide in the villages, special brooms are made of dried stems for sweeping the house to get rid of pests, and/or hung over the door as a talisman; Kozon yuvgich (Luffa cylindrica M.Roem.) [8]- cleansers to wash Kazans, when fruits ripe they take the form of sponges, which are used in the household; Kampir chopon (Trichodesma incanum (Bunge) DC.) [8] - old woman's coat, probably, grey hairy flower leaves associated to old woman's coat; Chupon thelpak (Matricaria chamomilla L.) [8] - shepherd's hat, popular plant is so named from its flowers resemblance to the headwear of shepherds; Tungiz tarok (Dipsacus laciniatus L.) [8] - boar's comb, dry sharp florets of the plants resemble a comb, Taroqbosh (Bromus tectorum L.) [8] comb + head, the shape of spikes resemble a comb.

\section{Conclusions}

The paper discusses the differential and universal features of English and Uzbek language image of the world, by means of motivational-contrastive analysis of plant names. For this purpose, first, we defined the process of naming the plants itself and explained the patterns of it. Then we selected the most popular association fields of naming plants Religion, Animal and Artifacts. We showed that the analysis of plant names within these fields can illustrate the unique and analogues features of English and Uzbek worldview. As we see, in the English and Uzbek language image of the world various properties of plants from the anthropocentric point of view are reflected differently. In particular, English people have a special tradition of associating religion with unusual features of plants; mostly positive features like beauty and medical properties are associated to Virgin Mary. That is due in all probability to the pre-Christian ancient tradition to associate everything that is incomprehensible or unknown with the deities. But this characteristic is not inherent in the Uzbek language. The analysis showed that Uzbek people usually do not associate plants with religion, because of some religious traditions.

However plant names referring to Animal field in both languages have some features in common. Both in English and Uzbek domestic animals (horse, camel, dog, donkey) are mainly used to fix some conventional, unwholesome or negative features of plants in the language, so that to show the most important one for human. From that point of view, we can say that cognitive associations about the plants are common for the languages. The further analysis proved the fact that 'dog' indicating plants' negative features (poisonous, smelly, worthless, wild, and thorny) in English can be replaced by 'donkey', and 'horse' indicating the plant's large size can be replaced by 'camel' in Uzbek, from the fact that camel and donkey are more common for Uzbek culture.

The analysis of artifacts as a component of plant names in English and Uzbek made us to assume that it depends on a culture what appropriate artifacts are used to name a plant. For instance, using items of woman clothing and toilette in plant names is more popular with English, whereas in Uzbek plant names artifacts mainly refer to everyday life of middle class people. Probably, higher social status of women in English culture determines the frequent use of attributes of the female world for the designation of plants. The Artifacts used in Uzbek plant names indicate that in the consciousness of Uzbeks plants are associated with those artifacts that are more important in everyday life that is reflected in the Uzbek language image of the world.

\section{REFERENCES}

[1] Вайсгербер Й.Л. (Weisgerber) Язык и философия// Вопросы языкознания №2, 1993.

[2] Сукаленко Н.И. (Sukalenko) Отражение обыденного сознания в образной языковой картине мира. Наукова думка, 1992.

[3] Etymonline dictionary website available at: http://www.etymonline.com Last accessed 2/02/2017

[4] Prior, R. C. A. On the Popular Names of British Plants, Being an Explanation of the Origin and Meaning of the Names of Our Indigenous and Most Commonly Cultivated Species. Third edition. London: Frederic Norgate; Edinburgh: Williams \& Norgate, 1878.

[5] Wright, E.M. Rustic Speech and Folk-Lore. Oxford: Horace Hart, 2014.

[6] Nowick, E. Historical Common Names of Great Plains Plants Volume I: Historical Names Lulu.com, 2014.

[7] Abdurakhmonov D., Sodikov T., Nosirov Sh., Turabova M., O`zbek shevalari leksikasi. Tashkent: 1991. 
[8] Sakhobiddinov S. O’rta osiyodagi foydali va zararli o`simliklarning maxalliy nomlari lug ati Tashkent: 1953.

[9] Panasenko N. Reflection of the naïve Christian worldview in the Romance, Germanic and Slavic phytonymic lexicon European Journal of Science and Theology 10(4): 167-183, 2014.

[10] Stepanova P. Language Image of the Human in Partners' (lovers') Names Inspired by Animals Linguistics and Literature Studies 3(2): 46-49, 2015.
[11] English Oxford living dictionaries. Website available at: https://en.oxforddictionaries.com/definition/dogfennel Last accessed 25/01/2017

[12] Biggam, C. Plants as metaphorical headgear in English. In: Anderson, W., Bramwell, E. and Hough, C. (eds.) Mapping English Metaphor Through Time. Oxford University Press: Oxford, pp. 47-65. 2016

[13] Tull, D. Edible and Useful Plants of Texas and the Southwest. 1999, p. 145 